\title{
ICTs and innovation for competitiveness: Evidence for Western Balkans vis-à-vis the European Union*
}

\author{
Olivera Kostoska ${ }^{1}$, Ilija Hristoski ${ }^{2}$
}

\begin{abstract}
The aim of this paper is to evaluate how well-prepared the Western Balkans (Albania, Macedonia, Montenegro and Serbia) are to join the EU in terms of competitiveness and to clearly identify the set of EU countries that would represent a 'real benchmark' when trying to assess the region's competitiveness. In 2010, the Europe 2020 strategy was proposed as a means of focusing the EU and its Member States on the main task of improving competitiveness and creating conditions for smart, sustainable and inclusive growth. As candidate countries for EU membership, Western Balkans are expected to act in accordance with these goals. Hence, this paper implements the Global Competitiveness Index 2015-2016 and a set of supplemental data analysis tools to assess both the level of competitiveness and the region's relative position vis-à-vis the EU member states. The results clearly show that the EU is far from a homogenous entity in terms of competitiveness, whilst the candidates expose a competitiveness profile similar to that of Central and Eastern Europe. Overall, the Western Balkans trail behind the EU-28 countries in building a knowledge-intensive economy and are significantly outdistanced in laying the foundations for 'smart growth', as the European economies press ahead.
\end{abstract}

Key words: GCI, ICTs, innovation, Western Balkans, EU

JEL classification: 052,057

\footnotetext{
* Received: 7-03-2017; accepted: 21-12-2017

1 Associate Professor, "St. Kliment Ohridski" University - Bitola, Faculty of Economics, Marksova 133, 7500 Prilep, Macedonia. Scientific affiliation: international trade and investment, productivity, innovation and European integration. Phone: +38948427020 . Fax: +38948426 927. E-mail: olivera.kostoska@uklo.edu.mk. Personal website: http://www.eccfp.uklo.edu.mk/ teachers/view/72 (corresponding author).

2 Assistant Professor, "St. Kliment Ohridski” University-Bitola, Faculty of Economics, Marksova 133, 7500 Prilep, Macedonia. Scientific affiliation: behavioural-based performability modelling and evaluation of e-Commerce systems, Petri Nets, discrete-event simulation, systems thinking approach and system dynamics. Phone: +38948427 020. Fax: +38948426 927. E-mail: ilija. hristoski@uklo.edu.mk.Personalwebsite: http://www.eccfp.uklo.edu.mk/teachers/view/76.
} 


\section{Introduction}

Policy makers around the globe express concerns about national competitiveness. Such concerns are not new; what seems new is its spread and intensity, fast technological changes, a response to globalization, shrinking economic distance and far-reaching liberalization (Lall, 2001). Conventionally, economists and economic historians since Adam Smith have talked over the economic growth primarily in the context of the national level - why some countries grow faster (in current terms, obtain the capabilities for sustained growth that make them more competitive) and become more affluent than others. While in neoclassical economics issues of national competitiveness came to assume a lesser degree of significance, as attention was moved away from questions of growth towards those of static resource allocation and efficiency, there was even less concern with the idea of competitiveness at the firm level (Cantwell, 2005). Recently, two related changes in economics and associated fields have been under way; one is the resurgence of a more general interest in the classical issues of national competitiveness, and the other is the rising attention paid to competitiveness at industry, region and firm-level. To start with the basic concept itself, economists use the term 'competitiveness' in different ways. One is entirely macroeconomic: the lack of competitiveness is a real exchange rate problem, alluding to a country at full employment "running a persistent (and unwelcome) currentaccount deficit which would in due course require adjustment, usually via a mixture of deflation and depreciation" (Boltho, 1996: 2). Competitiveness here is measured by "relative price and/or cost indices expressed in some common currency" (Boltho, 1996: 3). This expression assumes that underlying structural factors are constant, and give emphasis to the kinds of short-term macroeconomic management that affect relative prices of national products relative to other countries. Most researches, however, use the term more broadly. They concentrate on structural factors having an effect on long-term performance, and are essentially concerned with productivity, innovation and skills (Fagerberg, 1996). In fact, the issue related to innovation and competitiveness is sometimes referred to as being about the long-term technological competitiveness, as opposed to short-term price competitiveness. The winners from innovation are those that build appropriate capabilities, but they are localized and nationally differentiated, and so there can be a large number of successful players in the competitive game, each to some degree learning from and interacting with the somewhat alternative paths to capability creation being taken by others (Cantwell, 2005). In this context, there is hardly any to object that the pursuit of competitiveness through innovation is a national policy imperative, and a truly important objective as the role of innovation has grown in the modern knowledge-driven economy, even and especially for those countries that start behind and wish to catch up (Kostoska and Mitrevski, 2016).

Given the importance of competiveness analysis, a special emphasis should be placed on the competitiveness index, a composite indicator ranking countries in 
accordance with selected criteria and measures of national competitive ability. Such indices attract considerable attention; they are subject to an in-depth analysis, especially for those countries where competitiveness is considered a matter of national economic survival. While competitiveness indices have become very important in the policy discourse of many countries, it is necessary to caution that they are not exempt from criticism. In fact, the measurement procedure, the construction of indices and the country coverage have become fiercely debated issues among academics and politicians, especially concerning the global forecasts (Djogo and Stanisic, 2016; Segota et al., 2017). Perhaps the most fundamental problem is the lack of rigorous theoretical explanation which causes frequent changes in the evaluation models and makes unclear why some factors are important and others are not in assessing national competitiveness (Cho and Moon, 2013). In the selection and management of information, the competitiveness indices may be criticized both for the subjective character of a large portion of the information used and the arbitrary weight assigned to the components of the index (Önsel et al., 2008). In most composite indicators countries are clustered according to their stage of competitiveness. This classification, however, tends to be rather subjective or, when attempts are objectively made, is based mainly on per capita income. Subjectivity is also present when designing the threshold to detach one stage from another. Nonetheless, even a critic such as Sanjaya Lall has recognized the importance of and the useful role for competitiveness indices to benchmark national performance. Such indices can help researchers to evaluate economic issues in comparative terms, investors to allocate resources between nations and policy-makers to design and assess national competitive performance in the way technical benchmarking helps companies to evaluate and improve their competence against rivals (Lall, 2001). "The justification for using benchmarks (rather than theoretical norms) is simple: many aspects of performance can only be assessed with reference to actual practice. Theoretical norms are often difficult to construct with the precision needed to allow evaluations in a complex and fast changing world" (Lall, 2001: 1505). In other words, the composite indicators should ideally measure complex, multidimensional concepts which cannot be captured by a single indicator, e.g. competitiveness (OECD, 2008).

For more than three decades, the World Economic Forum's annual Global Competitiveness Report has analysed and benchmarked many factors reinforcing national competitiveness. Right from the beginning, the goal has been to provide insight and encourage discussion among the stakeholders about the best strategies and polices to help countries to succeed in dealing with obstacles to improving competitiveness. They define competitiveness as "the set of institutions, policies, and factors that determine the level of productivity of an economy" (World Economic Forum, 2015: 4). In fact, many determinants affect productivity and competitiveness. Whilst all variables are likely to be important for growth and competitiveness, they are not mutually exclusive, i.e. two or more of them may 
be crucial at the same time. In essence, the World Economic Forum has based its competitiveness analysis on the Global Competitiveness Index (GCI), a comprehensive device that estimates the microeconomic and macroeconomic foundations of national competitiveness. Since its first publication in 2005, GCI has become widely accepted as one of the main and most comprehensive assessments of the national competitiveness worldwide.

In view of that, this paper implements the GCI 2015-2016 to measure different aspects of competitiveness and estimate the level of productivity and competitiveness of the Western Balkans (Albania, Macedonia, Montenegro and Serbia). These countries have filed their candidatures to become EU member states. Thus, they may become full members at some point and must then abide by the EU's overall goals (Dragašević, 2014). At a time of public budget restraints, rising global competition and major demographic changes, Europe's competitiveness, its capacity to create new jobs to substitute for those lost in the worst financial and economic crisis of the past 80 years and, overall, its future living standards depends on its ability to foster innovation in products, services, business and social processes and models. That's why innovation, along with the use of Information and Communication Technologies (ICTs), is at the core of the Europe 2020, a 10year strategy launched in 2010 as a means of focusing the EU and its Member States on the important task of improving the EU's competitiveness and creating the conditions for smart, sustainable and inclusive growth. This renewed emphasis on research and innovation is also pertinent to the Western Balkans. As the recent financial crisis has revealed, macroeconomic imbalances, such as persistent current account and trade deficits, can severely undermine a certain country's resilience to economic shocks. Maintaining and improving competitiveness has therefore become of an increasing concern, and this applies especially to EU candidates whose economic growth models, based on the expansion of domestic consumption and a stagnant productivity, have been challenged in recent years (Vujović, 2014). These various arguments all suggest reasons for evaluating the competitiveness of candidate countries and the extent to which they will likely contribute to overall European competitiveness, providing a sense of the challenges they currently face, and making the case for estimating their relative position and 'distance' from the EU member states in the context of the most relevant GCI variables. The basic hypothesis is that the Western Balkans lag significantly behind the EU-28 countries in building a smart, innovation-based, knowledge-driven economy and are also outdistanced in laying the foundations for 'inclusive growth'.

The rest of the paper is organized as follows. Section 2 deals with the previous work on ICTs, innovation and productivity. Section 3 introduces the methodology and method of analysis. Section 4 contains description of data, documentation background and the results of the analysis. Section 5 explains the economic significance and messages of the results. Section 6 concludes and recommends. 


\section{Literature review}

Innovation has been recognized as one of the key determinants of both the individual business success and national economic growth. Strong innovation boosts the multifactor productivity, thus lifting a nation's international competitiveness, economic growth and living standards. Thanks to huge potentials to increase the consumer demand for higher quality products and a simultaneous decrease in production costs, innovation is seen as an important driver of firm performance. In essence, the relationship between $\mathrm{R} \& \mathrm{D}$, innovation and productivity is empirically examined by a large stream of literature (see Hall, 2011; Mohnen and Hall, 2013 for an overview). In order to make the most of the structure of richer micro data sets like the Community Innovation Surveys (CIS), Crepon et al. (1998) devised a structural model for estimating an extended knowledge production function. This model (also known as CDM framework) refines the standard knowledge production function approach of Griliches (1979) by way of examining different stages of the innovative process instead of directly appraising the relationship between R\&D expenditures and productivity. CDM models or the variants (see Hall, 2011 for a survey) are estimated by Griffith et al. (2006) for Germany, Spain, the UK and France, Parisi et al. (2006) and Conte and Vivarelli (2014) for Italy, GarcíaQuevedo et al. (2014) for Spain with differing effects for older and younger firms, and in a cross-country comparison for 18 OCED countries by Criscuolo (2009). Although the extent of the effect of R\&D on innovation fluctuates across the studies, the steady finding is that the likelihood of being an innovator is positively associated with the R\&D intensity. Furthermore, most of the studies find positive relationship, albeit somewhat noisy, between the firms' innovation and productivity. Nevertheless, the positive relation is primarily attributable to product innovation, while the impact of process innovation is more variable, and often negative. Hall (2011: 15) suggests that this can be interpreted in a way that "it is possible that there is so much measurement error in the innovation variables that only one of the two is positive and significant when entered in the productivity equation". Based on a modified CDM model, Baumann and Kritikos (2016) have recently examined the extent to which micro firms are successful in their attempts to innovate (with or without formal R\&D spending) and the applicability of the existing empirical evidence on the relationship between $\mathrm{R} \& \mathrm{D}$, process and product innovation, and productivity to a sample of micro-sized firms.

As already mentioned, the early contributions to analysis of the impact of innovation on productivity (Griliches, 1979) have predominantly assessed the contribution of research and development (R\&D) expenditures to economic growth. Over the recent decades, literature dealing with the engines of productivity growth has extended its scope to include other types of investment. Since the mid1990s, the fast growth of the US economy, the extensive introduction of ICTs and the series of other developments have renewed the interest on dynamics and 
sources of productivity growth (Pianta and Vaona, 2006). Conceptually, ICTs affect growth and productivity both directly and indirectly. First, productivity growth and technological improvements in ICT-producing sectors have the potential to directly affect aggregate productivity proportional to the size of the ICT sector (Gordon, 2000 and 2012; Jorgenson et al., 2002 and 2008; van Ark et al., 2008). Given that such technologies play a vital role in the generation, storage and transmission of information and in the reduction of market failures associated with information asymmetries (Gilchrist et al., 2001; Atrostic et al., 2004; Arvanitis and Loukis, 2009; Cardona et al., 2013), ICTs have an indirect effect on productivity that is mostly observable in sectors using them. In particular, "ICT are enablers of product, process and organizational innovation in ICT-using sectors, and this, according to Bresnahan and Trajtenberg (1995), qualifies them as General Purpose Technologies (GPT): technologies that are pervasive - i.e. can be applied to several production processes - allow continuous improvements and experimentation and facilitates innovation in using sectors (through co-inventions)" (Biagi, 2013: 14).

In fact, the contribution of ICTs to growth is one of the research issues standing at the forefront of economics in the last 20 years. The research interest was especially inspired by the so-called Solow paradox or productivity paradox, when, in 1987, the Nobel Prize-winning economist Robert Solow noted, "you can see the computer age everywhere but in the productivity statistics" (Solow, 1987: 36). This led to an intense effort in the 80 s and 90 s to measure the impact of ICTs on growth. The majority of literature was based on macro data, while the most popular analytical framework was growth accounting. What this approach proposes is that rapid technological progress in the ICT-producing sector, particularly semiconductors, after 1994 led to a rapid decline in quality-adjusted prices for ICT goods. This was reflected by total factor productivity (TFP) growth in the ICT-producing sectors and ICT capital deepening in other sectors. This has resulted in productivity growth (European Commission, 2010). Given that the productivity resurgence of the U.S. was not shared by the similar EU performance, interest emerged among scholars to understand if the U.S.-EU productivity gap was in a way attributable to ICTs. Many studies have actually confirmed the importance of ICTs for the improved productivity performance of the U.S. in the 1990s (Oliner and Sichel, 2000 and 2002; Jorgenson et al., 2002; Daveri, 2003). Similar research on individual countries has been provided for the United Kingdom (Oulton and Srinivasan, 2005; Marrano et al., 2009), but also conducted in an international comparative perspective (Basu et al., 2004; Inklaar et al., 2007; Van Ark et al., 2008). A recent study that established growth accounting as a well-tested approach is that of Jorgenson and Timmer (2011). The authors have actually provided new evidence on patterns of structural change in advanced economies.

Irrespective of its merits, the growth-accounting approach raises some methodological problems (Biagi, 2013). To overcome these disadvantages and restrictions, some 
scholars have examined an econometric approach, which does not rely on the very strict assumptions imposed by the growth accounting. Strictly speaking, the academic research, due to concerns about aggregation and other biases, has shifted towards more micro-level analysis in order to capture better the evidence of the multifaceted improvements that ICTs can provide. This type of literature makes possible to assess properly the indirect effects of ICT investment, i.e. those that emerge in ICT-using sectors and are related to GPT nature of ICTs. The estimates using micro-data indicate that ICT capital tends to exhibit excess return that is due either to the true spillover effects or the errors in measuring inputs correlated with ICT (Brynjolfsson and Hitt, 1995 and 2003; Rincon and Vecchi, 2010; van Reenen et al., 2010; Bloom et al., 2012). Another strand of research looks upon ICT as an input, both of the production function and, even more importantly, of the knowledge production function (Aboal and Tacsir, 2015). Whilst ICT capital (the ICT variable used in growth accounting and in most micro-oriented estimates) catches the overall value of the capital invested in ICTs, the ICT usage variables permit the observers to get better perception of the strategic ICT usage by companies in their organizational structures (Biagi, 2013). Particularly interesting is the recent attempt of Polder et al. (2010) to merge the literature on productivity and innovation with that of ICT and productivity (through complementary assets). Despite the fact that this literature is still in its early stages, it has a huge potential to provide very interesting insights into the relationship between the ICT usage and innovative performance of companies.

\section{Methodology and method of analysis}

Given the importance and expedience of composite indices to gauge the complex and multidimensional phenomena, this paper employs the GCI ranks and values to conduct two types of analyses. The first one refers to a descriptive analysis of the GCI scores for Western Balkans (WB) in order to assess each country individual position and performance on a global scale, while the second estimates the competitiveness performance of WB vis-à-vis the EU-28 member states. Based on descriptive statistical methods, the latter opts to evaluate the percentage change (as a measure of deviation) between the respective indicator values for WB average with reference to the EU-28 mean values. With the aim of visualizing the best and worst performers and the interquartile range (from the 75th downto the 25th percentile) by GCI pillars, we further implement a five-number summary statistics accompanied by a corresponding Box \& Whisker plot. Moreover, the article uses both the Euclidean and statistical distances, as well as the hierarchical cluster analysis approach to measure the WB 'distance' from each EU member state within the multi-dimensional dataspace.

The Euclidean distance, $D_{i j}$, is a well-known measure of distance between two observations, $i$ and $j$, in a $p$-dimensional dataspace. Assuming that $i$ represents the 
Western Balkans, $j(j=1, \ldots, 28)$ - the EU member states, $p_{k}(k=1,2, \ldots, 69)-\mathrm{GCI}$ indicators, $x_{i k}(k=1,2, \ldots, 69)$ - the WB average indicator values, and $x_{j k}(j=1, \ldots, 28$; $k=1,2, \ldots, 69)-$ the indicator values for each EU country, the Euclidean distance is given by (1).

$$
D_{i j}=\sqrt{\sum_{k=1}^{p}\left(x_{i k}-x_{j k}\right)^{2}}
$$

The statistical distance, $S D_{i j}$, is obtained from Euclidean distance, once the latter is adjusted to take into account the variance of the variables, $s_{k}^{2}$, as in (2), where $s_{k}$ stands for a standard deviation of the variable $p_{k}(k=1,2, \ldots, 69)$.

$$
S D_{i j}=\sqrt{\sum_{k=1}^{p}\left(\frac{\left(x_{i k}-x_{j k}\right)}{s_{k}}\right)^{2}}
$$

Hierarchical cluster analysis (HCA) is one of the most commonly used exploratory techniques for identifying data structures. As with other clustering algorithms, HCA separates the groups (clusters) of similar cases/observations, based upon their scores on a set of Interval/Ratio-level measures. By virtue of clustering variables together in a manner somewhat similar to the factor analysis, HCA produces a series of models with cluster solutions generally ranging from 1 (all cases are classified into a single cluster) to $\mathrm{N}$ (all cases belong to an individual cluster). In fact, hierarchical cluster analysis is an agglomerative method where all cases start in their own distinct cluster. The two 'closest' (most similar) clusters are then combined - a step that repeats until all cases are placed into a minimally specified number of clusters (ultimately, into a single cluster). At the end, the optimal number of clusters is specified out of all cluster solutions.

Given that the number of clusters is not predefined, we consider this kind of multivariate statistical analysis the most appropriate to conduct here. Our goal is to provide clusters of countries that reliably distinguish from each other in terms of their intrinsic characteristics vis-à-vis all 69 GCI indicator values, which represent Interval-level measures on a 1-7 scale. The HCA analysis conducted here includes five different cluster solutions ( $\mathrm{N}=2$ to $\mathrm{N}=6$ clusters). This is because we keep in mind that there is always a trade-off between the number of clusters and their sizes, i.e. the more the clusters are, each of them contains more homogeneous, yet smaller group of countries.

When it comes to clustering methods, we have opted for the Ward's method. The latter assumes the concept of distance as that of all clusters relative to the grand average of the sample. Thanks to the use of $F$ value (like ANOVA) that maximizes the significance of differences between clusters, the Ward's method has the highest 
statistical power among other clustering methods. The downside is that this method is prone to outliers and generally tends to produce relatively small clusters of approximately equal size, which is not always a desirable feature.

Finally, we have opted for the Squared Euclidian Distance measure, which is the most commonly used measure for scale data, primarily for its ability to increase the importance of large distances, while gravely weakening the position of the small ones (Hristoski and Kostoska, 2017).

\section{Empirical data and analysis}

Building on Klaus Schwab's original idea from 1979, since 2005 the World Economic Forum has published the Global Competitiveness Index (GCI) developed by Xavier Sala-i-Martín in cooperation with the Forum (World Economic Forum, 2015). Technically, the GCI is a composite indicator made up of 3 main subindexes, 12 pillars and 114 individual indicators that capture the concepts that matter for productivity and are distributed across different pillars (Figure 1). The computation of the Index is based on successive aggregations of scores from the most disaggregated level (i.e. the indicator level) to the highest level (i.e. overall GCI score). While all pillars will matter to a certain extent for all economies, it is quite clear that they will affect different countries in a different manner, i.e. the best way for one economy to improve its competitiveness is not the same as another. This is caused by the fact that various countries are in different stages of development, as proxies by their GDP per capita and the share of exports represented by raw materials (World Economic Forum, 2015).

According to the well-known economic theory of stages of development ${ }^{3}$, the GCI assumes that, in the first stage the countries are factor-driven and they compete based on their factor endowments - mainly unskilled labor and natural resources. Companies compete on basis of prices and sell elementary products or commodities with their low productivity revealed in low wages. Maintaining competitiveness at this phase depends entirely on well-functioning institutions, well-developed infrastructure, stable macroeconomic environment and healthy workforce that has obtained at least a basic education.

\footnotetext{
3 Perhaps the most famous theory of stages of development was elaborated by the American historian Rostow (1960). However, Porter's (1990) theory of stages is adapted to apply the concept of the stages of development to weight the Global Competitiveness Index (Sala-i-Martín et al., 2007).
} 
Figure 1: The complex structure of the Global Competitiveness Index

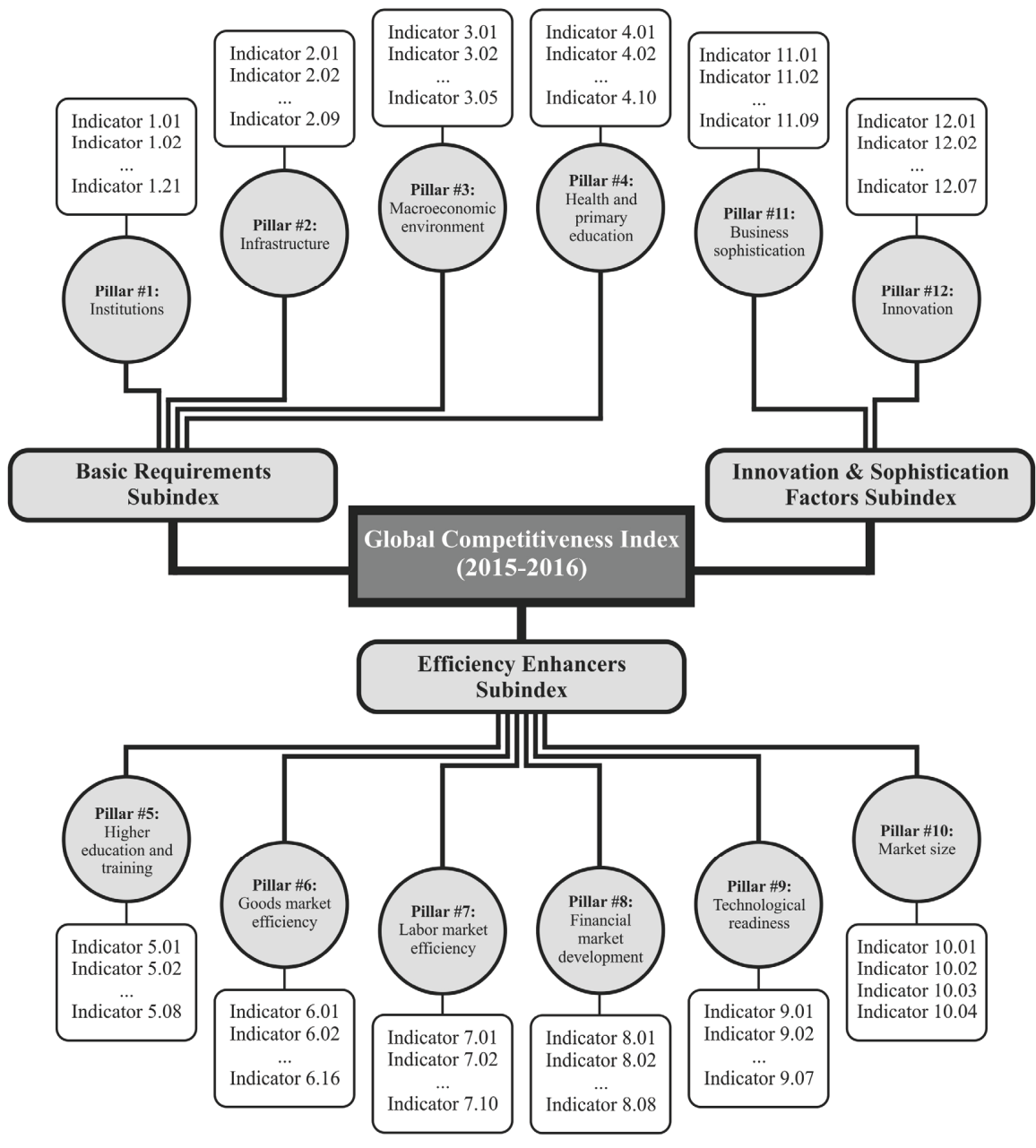

Source: Authors' original representation

As country becomes more competitive, productivity and wages will increase with advancing development. The countries will move into the new stage of development (i.e. the efficiency-driven), and they have to start developing moreefficient production processes and increase product quality since wages have increased and they cannot push the prices up. The competitiveness here is mostly driven by higher education and training, efficient goods markets, well-functioning labor markets, developed financial markets, the ability to exploit the benefits of existing technologies, and a large domestic or foreign market.

Finally, when moving into the innovation-driven stage, the capacity of the countries to sustain the highly increased wages and the associated standard of living depends 
entirely on the ability of their firms to compete with new and unique products. At this stage, businesses need to compete by producing new and different goods using the most sophisticated production processes and by innovating new ones (World Economic Forum, 2015). The GCI takes the stages of development into consideration by assigning higher relative weights to those pillars that are more important for a particular country given its stage of development. In order to implement such concept, the pillars are grouped into three subindexes, each essential to a particular stage of development, i.e. the 'basic requirements subindex' combines those pillars most relevant for countries in the factor-driven stage; the 'efficiency enhancers subindex' includes those pillars crucial for countries in the efficiency-driven stage; and the 'innovation and sophistication factors subindex' groups the pillars critical to countries in the innovation-driven stage. Those countries falling between two of the three stages are regarded as being 'in transition'.

This paper uses the extensive data compendium ${ }^{4}$ of the GCI 2015-2016 provided by the Global Competitiveness Report 2015-2016, as a secondary data source. For the purpose of analyses conducted here, we thought it would be useful and the most appropriate to exclude those pillars that are the most critical for countries in the factor-driven stage (i.e. the basic requirements subindex). The reason for this is twofold; first, given their particular stage of development, such pillars are far less important for both Western Balkans and the EU countries [the former are in the efficiency-driven (i.e. stage 2), while the most of latter are either in innovationdriven (i.e. stage 3 ) or in transition from stage 2 to stage 3]; second, the paper tries to gauge the level of competitiveness of the candidate countries vis-à-vis the EU-28 member states. As Europe moves away from the crisis, it becomes more important than ever to invest in competitiveness-enhancing measures that will only play out in the medium to longer term (e.g. education, R\&D, innovation and ICTs) in order to meet the goals of transforming the EU into "a smart, sustainable and inclusive economy, delivering high levels of employment, productivity and social cohesion" (World Economic Forum, 2014: v). Hence, this paper focuses on those pillars (i.e. efficiency enhancers and innovation and sophistication factors subindexes) and indicators thereof, which are the most relevant to determine whether the Western Balkan candidates are ready to act in accordance with the EU's overall goals and join the Union in terms of competitiveness.

All indicator values required and presented as WB average figures for certain assessments are justified with the argument that the region is rather a homogenous entity in terms of competitiveness, i.e. large disparities do not exist among individual countries, with some performing far better or worse than others. In order to give grounds for this statement, it is first necessary to assess the magnitude of dispersion of

$\overline{4}$ The dataset on the GCI indicator values and ranks is publicly available, and can be freely accessed at http://reports.weforum.org/global-competitiveness-report-2015-2016/. 
indicator values around the assumed mean value. Using the Z-score transformation, the results indicate, how many standard deviations the value of a given variable (e.g. the value of a particular GCI indicator for the group of four WB countries) is 'far' from its arithmetic mean (e.g. the mean value of a particular GCI indicator for the group of four WB countries). Since Z-scores are normally distributed with a mean of 0 and a standard deviation of $1,68.26 \%$ of all scores are expected to fall within the interval $[-1,+1], 95.44 \%$ of all scores are expected to fall within the interval $[-2,+2]$, and $99.74 \%$ of all scores are expected to fall within the interval $[-3,+3]$. Our findings reveal that, $183(66.30 \%)$ out of 276 computed Z-scores ( 4 countries $\times 69$ indicators) belong to the interval $[-1,+1]$, which is quite close to the expected value, whilst 276 out of $276(100.00 \%)$ belong to the interval $[-2,+2]$. Because of the low dispersion of particular GCI scores around their mean value (across the four WB countries), it appears quite justified to use the average values for the WB region as a whole.

Given that the measurement scales of the indicator values differ in the original dataset, we conduct, prior to introducing the concept of distance, a Min-Max scaling (i.e. normalization) data pre-processing technique to a number ${ }^{5}$ of GCI indicator values in order to convert the input data into a unified range of values on a 1-7 scale (the lowest and the highest score possible). As an alternative approach to Z-score normalization/standardization, the Min-Max normalization scales the data $a[i]$ within an array to new values $a^{\prime}[i]$, that belong to a fixed, pre-defined bounded range $[x, y]$, as in (3). For those GCI indicators ${ }^{6}$ set to obtain worse outcomes at higher values and vice versa, the Min-Max formulation translates into (4), so that we could still preserve the lowest $(x=1)$ and the highest value $(y=7)$. This approach generally produces smaller standard deviations in the array, which can suppress the effects of outliers. As such, the scaling is intended for use in the concept of distance, particularly when the $x$ and $y$ range of data is known a priori.

$$
\begin{aligned}
& a^{\prime}[i]=\frac{(y-x)}{\left(\max _{i}(a[i])-\min _{i}(a[i])\right)} \times\left(a[i]-\min _{i}(a[i])\right)+x \\
& a^{\prime}[i]=\frac{(x-y)}{\left(\max _{i}(a[i])-\min _{i}(a[i])\right)} \times\left(a[i]-\min _{i}(a[i])\right)+y
\end{aligned}
$$

\footnotetext{
5 These include: Secondary education enrollment, gross \% (5.01); Tertiary education enrollment, gross \% (5.02); Imports as a percentage of GDP (6.14); Women in labor force, ratio to men (7.10); Legal rights index, 0-12 (best) (8.08); Individuals using Internet, \% (9.04); Fixed broadband Internet subscriptions/100 pop. (9.05); Int'l Internet bandwidth, $\mathrm{kb} / \mathrm{s}$ per user (9.06); Mobile phone subscriptions/100 pop. (9.07); GDP (PPP\$ billions) (10.03); Exports as a percentage of GDP (10.04); and PCT patents, applications/million pop. (12.07).

6 These include: No. procedures to start a business (6.06); No. days to start a business (6.07); Total tax rate, \% profits (6.05); Trade tariffs, \% duty (6.10); and Redundancy costs, weeks of salary (7.04).
} 
As described earlier, to gauge the WB's competitiveness efforts, the challenges they currently face and their relative position vis-à-vis the EU-28, this paper carries out four types of analyses. First, it describes the performance of individual Western Balkan countries, analysing their competitiveness profiles and taking stock of the change in their relative performances since 2007-2008. Second, the paper evaluates, at the GCI indicator level, the performance of WB vis-à-vis the European average in order to provide a framework for identifying the overall challenges and weaknesses that need to be taken into account when aiming to build a competitive region. So that we could assess the dispersion in performance across the Western Balkan and European countries in the eight dimensions, the further analysis separates the best performers from the worst and identifies the interquartile range. Finally, the paper estimates the 'distance' between the Western Balkans and individual EU countries, and illustrates the overall picture of the hierarchical clustering approach.

Albania is the most recent candidate country (as of June 2014). It is ranked 93th/140 in GCI 2015-2016, moving up 16 places since the 2007-2008 assessment (109th/131). The country has seen $+50.54 \%$ improvement in 'higher education and training' and $+31.69 \%$ in 'innovation', but has worse outcomes in 'financial market development' $(-11.43 \%)$ and 'labour market efficiency' $(-3.61 \%)$ (Figure 2a).

For Macedonia, a candidate country since 2005, accession negotiations have yet to be opened. In terms of its performance along the overall GCI, Macedonia outperforms the rest of Western Balkan countries. Namely, the country has improved by 34 places since 2007-2008 and ranks 60th in the latest edition. The results confirm that Macedonia has greatly advanced its 'technological readiness' (+49.91\%) (Kostoska and Hristoski, 2016), keeping the direction along which there is no negative change in any pillar of competitiveness (Figure $2 b$ ).

In Montenegro, a candidate country since 2010, accession negotiations opened on 29 June 2012. Montenegro is ranked 70th overall, rising 12 places since the 2007-2008 assessment. The country has seen improvements in the 'market size' pillar $(+67.38 \%)$, but needs to address challenges related to its 'financial market development' (-10.44\%) (Figure 2c).

Finally, Serbia was granted the EU candidate status in March 2012, while accession negotiations were launched in January 2014. The country has fallen 3 places since 2007-2008 and ranks 94th overall in the Index, the lowest position among the Western Balkans in the latest ranking. Serbia faces multiple challenges in the areas of 'financial market development' (-13.46\%), 'business sophistication' $(-11.03 \%)$, 'innovation' $(-5.71 \%)$ and 'labour market efficiency' (-3.61\%). It is also notable that the country registered certain improvements in its 'technological readiness' pillar (+33.61\%) (Figure 2d). 
Olivera Kostoska, Ilija Hristoski $\bullet$ ICTS and innovation for competitiveness: Evidence... Zb. rad. Ekon. fak. Rij. • 2017 •vol. 35 ・ no. 2 • 487-518

Figure 2: Percentage change in the value of GCI pillars for Western Balkans 20152016 vs $2007-2008$

(a)

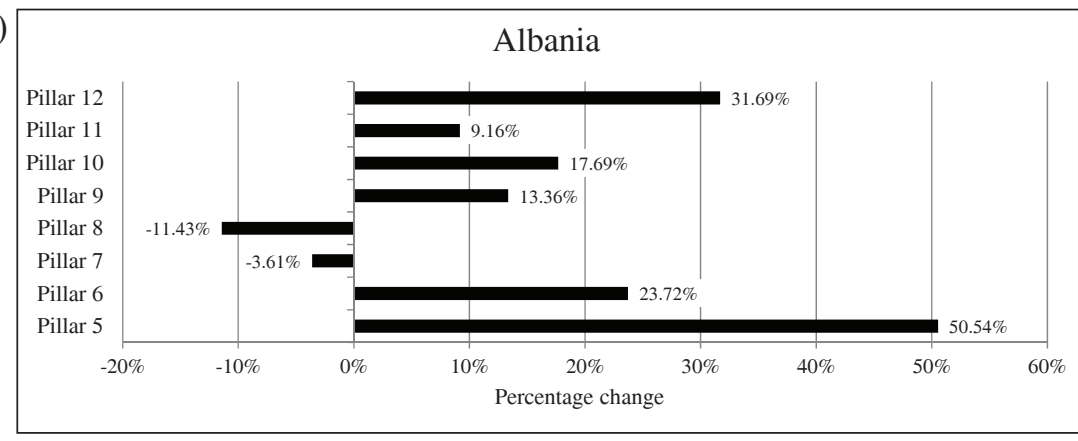

(b)

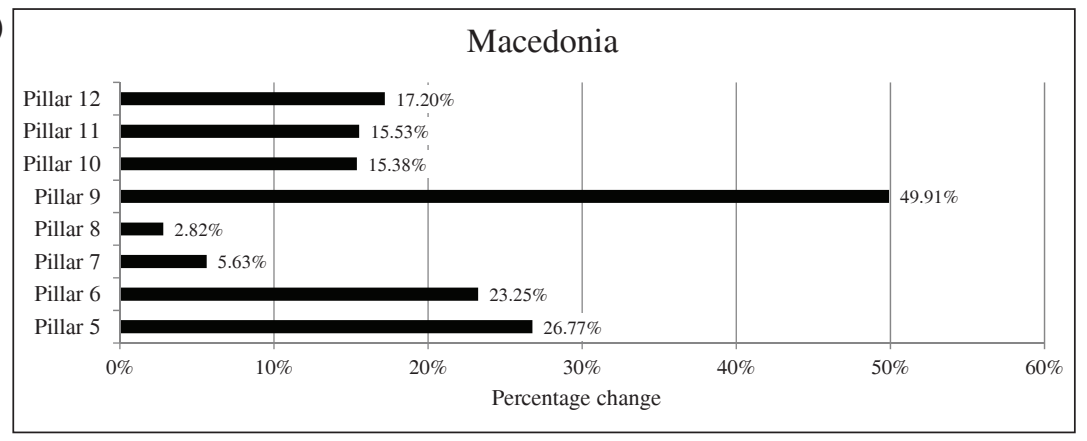

(c)

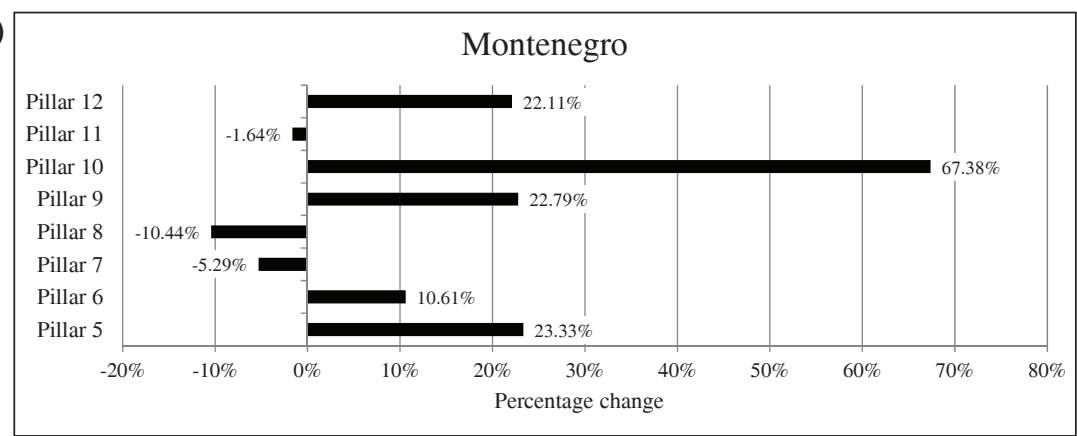

(d)

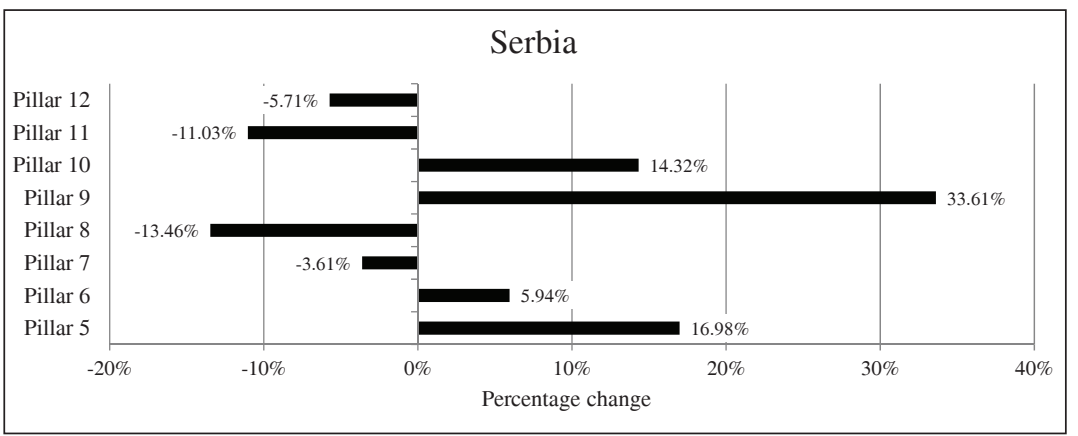

Source: Authors' calculations 
In order to examine how the candidate countries perform with respect to EU, this section further compares the pertinent averages of each GCI indicator values for Western Balkans and the EU-28, i.e. the percentage change as a measure of deviation between the respective variables (Figure 3).

Figure 3: WB vis-à-vis EU-28: deviation between the GCI indicators average value

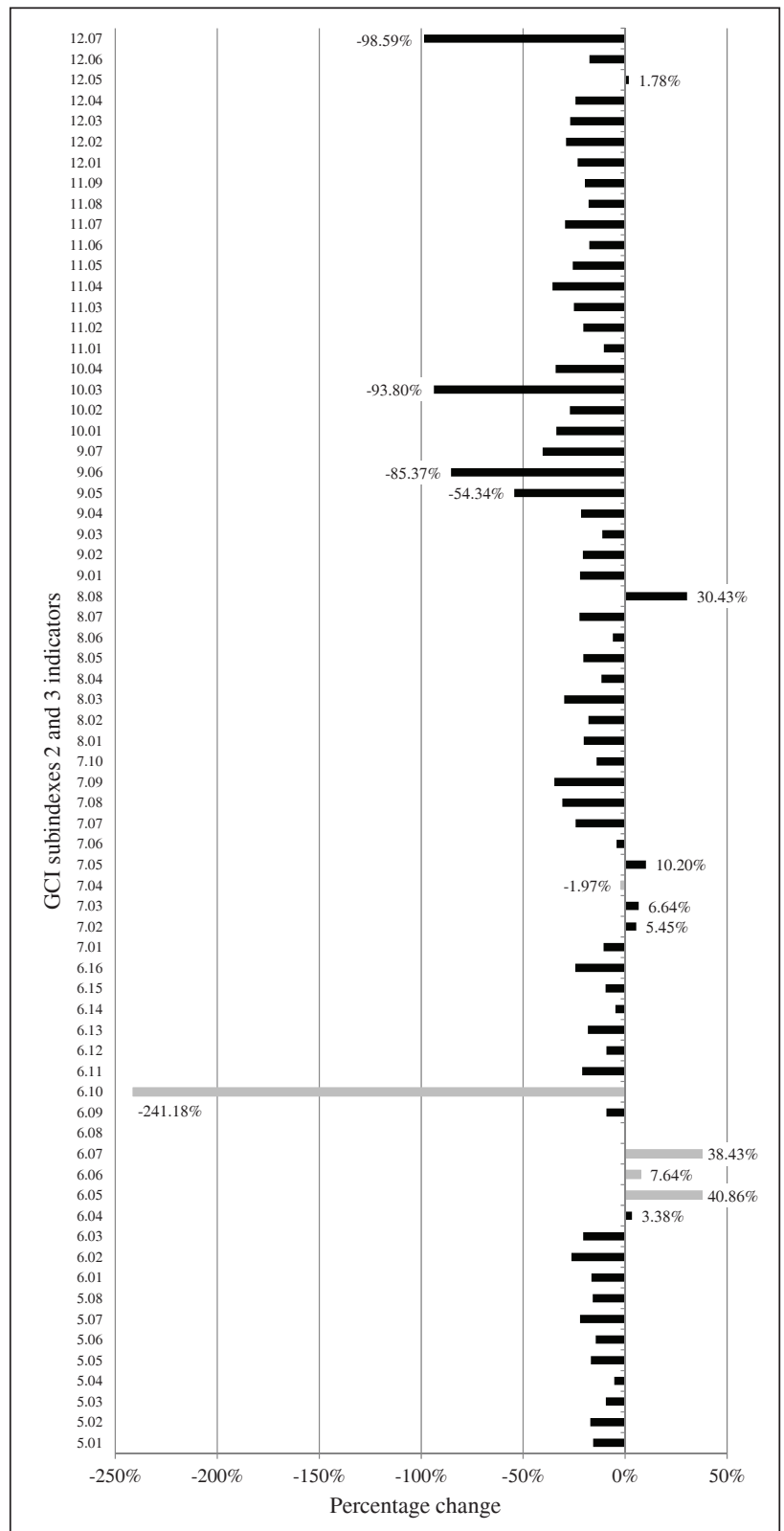

Source: Authors' calculations 
The findings suggest that the performance of Western Balkan countries lags considerably behind the EU-28 average for almost all indicators (59 out of 69).

The previous assessments show the diversity of competitive performance and provide a clear evidence of the most notable disparities between the two groups of countries. That's the reason why we should further examine the nature and measure the degree of relationship between WB and the EU-28 average indicator values.

We consider the null hypothesis specifying that no statistically significant correlation exists between WB and the corresponding EU-28 indicator values. As shown in Table 1, there is a moderate, yet positive linear correlation (Pearson Correlation $=0.678$ ) between the $\mathrm{N}=69 \mathrm{GCI}$ indicator values. Assuming a $99 \%$ confidence interval, the correlation is statistically significant $($ Sig. $(2$-tailed $)=p$ $=0.000<1 \%$ ) and thus, the null hypothesis is rejected. In other words, there is conclusive evidence about the significance of the association between the observed variables. The scatterplot in Figure 4 and the inscribed 'best fit' line illustrate such moderately intense, yet positive linear correlation.

Table 1: The degree of relationship between WB and EU-28 (indicator-level)

\begin{tabular}{|l|l|r|r|}
\hline \multicolumn{2}{|c|}{ Correlations } & $\begin{array}{c}\text { Western Balkans } \\
\text { average }\end{array}$ & $\begin{array}{r}\text { EU-28 } \\
\text { average }\end{array}$ \\
\hline Western Balkans average & Pearson Correlation & 1 & $.678^{* *}$ \\
& Sig. (2-tailed) & 69 & .000 \\
& $\mathrm{~N}$ & $.678^{* *}$ & 69 \\
\hline EU-28 average & Pearson Correlation & .000 & 1 \\
& Sig. (2-tailed) & 69 & 69 \\
& $\mathrm{~N}$ & & \\
\end{tabular}

Note: ** represents statistical significance at the 0.01 level (2-tailed).

Source: Authors' calculations

Since it is never appropriate to conclude that changes in one variable cause changes in another based on correlation only, i.e. the correlation analysis itself cannot determine whether the relationship between the observed variables is causal, in this particular case the correlation analysis results can be interpreted as follows: Western Balkans 'keep pace' with, or 'follow' the trend of the EU's GCI performance in a rather moderate and linear 'manner'. 
Figure 4: The degree of relationship between the WB and EU-28 (indicator-level)

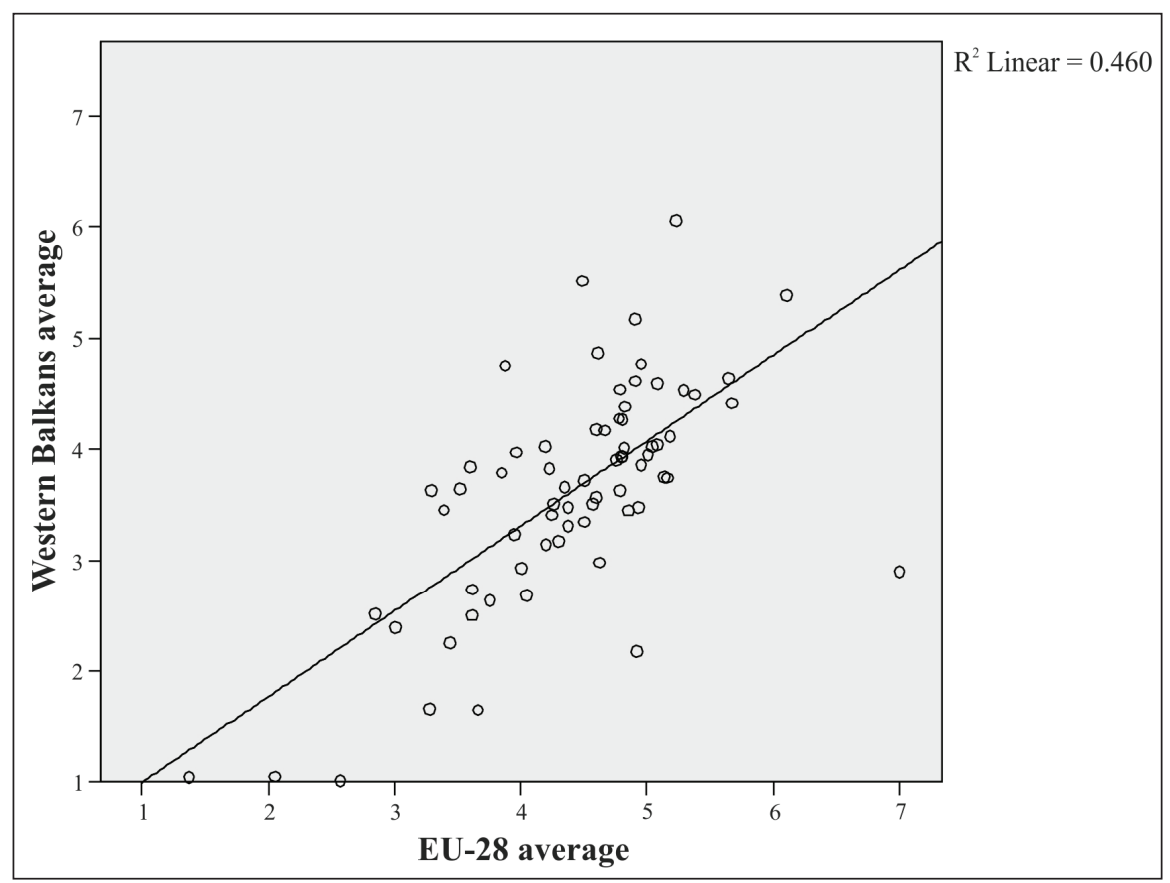

Source: Authors' calculations

In order to divide among the best- and worst-performing countries and to identify the interquartile range, we look at the distribution of GCI values for Western Balkans and each EU country by individual GCI pillars (Figure 5). The five-number summary stipulates that both WB and the rest of European Union are outperformed at all pillars by the Western European countries [Germany (pillar 10 - market size; pillar 11 - business sophistication), Luxembourg (pillar 6 - goods market efficiency; pillar 9 - technological readiness) and UK (pillar 7 - labour market efficiency)] and Finland [pillar 5 (higher education and training); pillar 8 (financial market development) and pillar 12 (innovation)]. 
Figure 5: Score dispersion among WB and EU-28 by GCI pillars (Score 1-7)

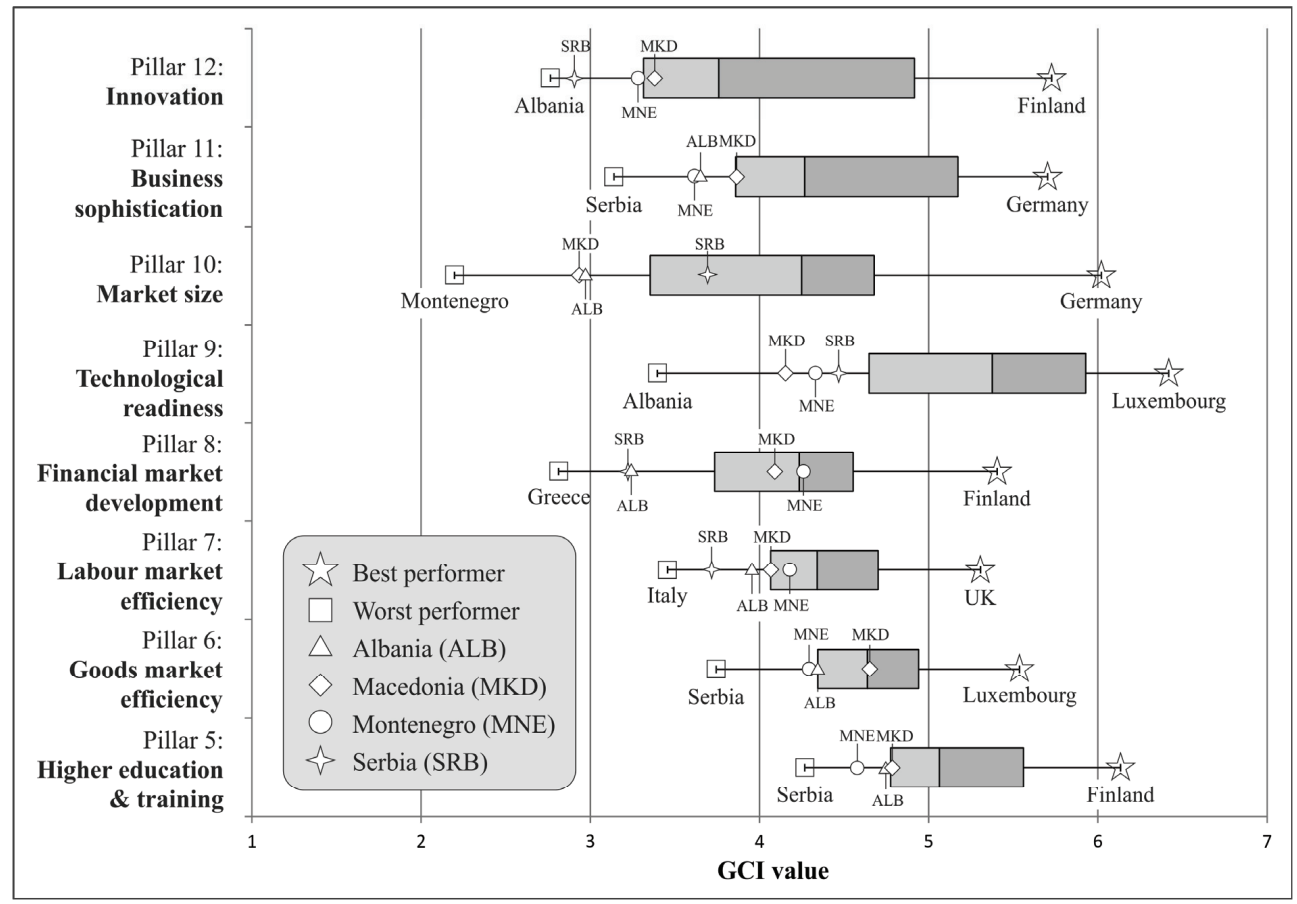

Source: Authors' calculations

All Western Balkan countries appear better placed than the worst-performing economies [Greece - pillar 8 (financial market development); Italy - pillar 7 (labour market efficiency)], but a large majority of them (Albania, Montenegro and Serbia) are categorized as the lowest-achieving countries in six out of eight GCI pillars [Albania (pillar 9 - technological readiness; pillar 12 - innovation); Montenegro (pillar 10 - market size) and Serbia (pillar 5 - higher education and training; pillar 6 - goods market efficiency; pillar 11 - business sophistication)]. In general, the Western Balkan countries are consistently below the median in all cases except the 6th pillar (goods market efficiency) and the 8th pillar (financial market development).

Next to the previous descriptive measures, the paper further examines the 'distance' between WB average and each EU country within the normalized GCI space. For that reason, we use two distance measures, viz. the Euclidean distance and the statistical distance (Figure 6). The findings point to a slight difference between the two types of distance. The EU countries with the shortest 'distance' from WB are Bulgaria, Romania, Croatia, Cyprus, Latvia and Hungary. Quite the opposite, the Western Europe (Luxemburg, Netherlands, Germany, UK and Belgium) and the Nordics (Finland, Sweden and Denmark) are the most 'distant' countries from the 
Olivera Kostoska, Ilija Hristoski •ICTs and innovation for competitiveness: Evidence...

Western Balkans. These findings confirm yet again the results already obtained by the five-number summary statistics.

Figure 6: Euclidean and statistical 'distance' between WB average and each EU-28 country

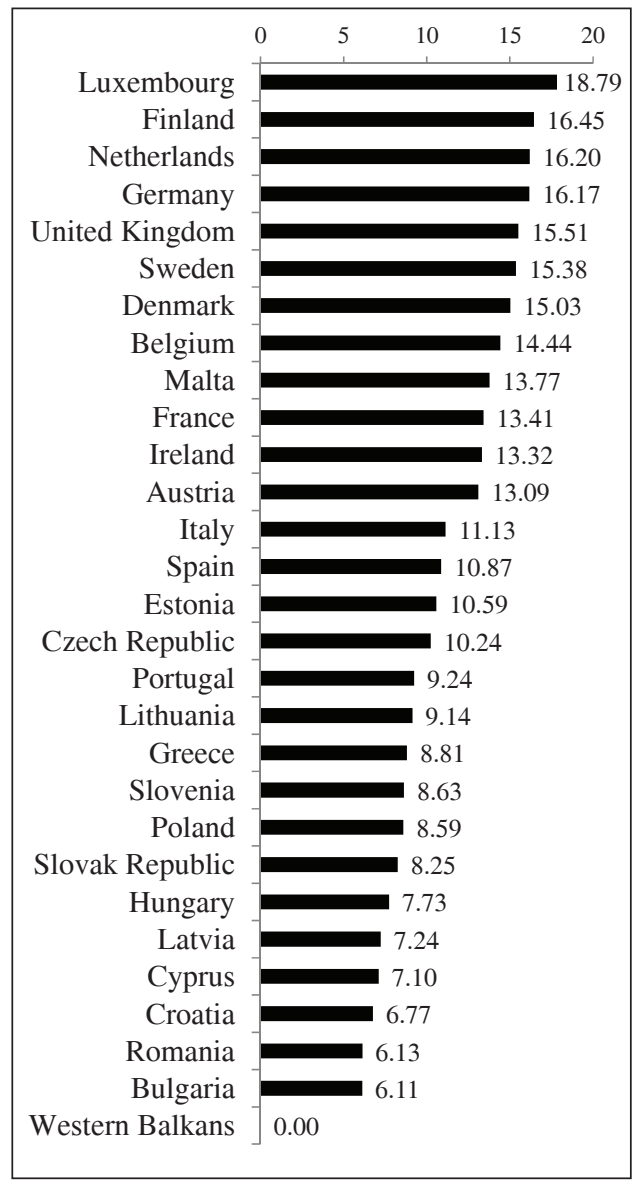

(a) Euclidean distance

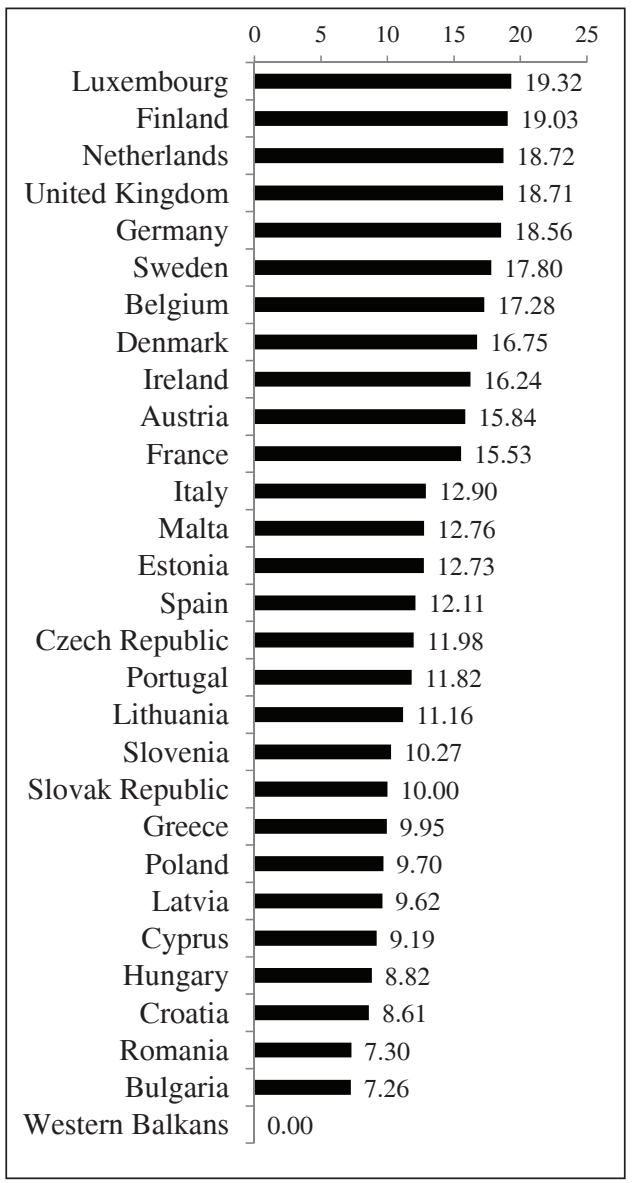

(b) Statistical distance

Source: Authors' calculations

The previous results have finally been completed by the hierarchical clustering analysis approach. Data presented in Table 2 clearly show that countries fall into different groups, which include a diverse number of clusters (i.e. $\mathrm{N}=2$ to $\mathrm{N}=6$ ). It is noteworthy that the group consisting of $\mathrm{N}=6$ clusters entirely reflects the grouping of the EU countries relative to Western Balkans with respect to the Euclidean distances, i.e. cluster \#1 corresponds to WB and Bulgaria that belong to efficiency-driven stage of development, and some EU countries falling between stage 2 and stage 3 (Croatia, 
Hungary and Romania) (Table 3). In addition, these countries always belong to the same cluster (cluster \#1), regardless of the number of clusters chosen, stressing out the intensive, yet steady mutual similarity among them, invariant vis-à-vis the grouping strategy (Table 2).

Table 2: Cluster membership of WB and EU-28 ( $\mathrm{N}=2$ to $\mathrm{N}=6$ clusters)

\begin{tabular}{|l|c|c|c|c|c|}
\hline \multicolumn{1}{|c|}{ Case } & 6 Clusters & 5 Clusters & 4 Clusters & 3 Clusters & 2 Clusters \\
\hline 1: Albania & 1 & 1 & 1 & 1 & 1 \\
\hline 2: Macedonia & 1 & 1 & 1 & 1 & 1 \\
\hline 3: Montenegro & 1 & 1 & 1 & 1 & 1 \\
\hline 4: Serbia & 1 & 1 & 1 & 1 & 1 \\
\hline 5: Austria & 2 & 2 & 2 & 2 & 2 \\
\hline 6: Belgium & 2 & 2 & 2 & 2 & 2 \\
\hline 7: Bulgaria & 1 & 1 & 1 & 1 & 1 \\
\hline 8: Croatia & 1 & 1 & 1 & 1 & 1 \\
\hline 9: Cyprus & 1 & 1 & 1 & 1 & 1 \\
\hline 10: Czech Republic & 3 & 3 & 3 & 1 & 1 \\
\hline 11: Denmark & 2 & 2 & 2 & 2 & 2 \\
\hline 12: Estonia & 3 & 3 & 3 & 1 & 1 \\
\hline 13: Finland & 2 & 2 & 2 & 2 & 2 \\
\hline 14: France & 4 & 2 & 2 & 2 & 2 \\
\hline 15: Germany & 4 & 2 & 2 & 2 & 2 \\
\hline 16: Greece & 1 & 1 & 1 & 1 & 1 \\
\hline 17: Hungary & 1 & 1 & 1 & 1 & 1 \\
\hline 18: Ireland & 2 & 2 & 2 & 2 & 2 \\
\hline 19: Italy & 5 & 4 & 3 & 1 & 1 \\
\hline 20: Latvia & 3 & 3 & 3 & 1 & 1 \\
\hline 21: Lithuania & 3 & 3 & 3 & 1 & 1 \\
\hline 22: Luxembourg & 6 & 5 & 4 & 3 & 2 \\
\hline 23: Malta & 6 & 5 & 4 & 3 & 2 \\
\hline 24: Netherlands & 2 & 2 & 2 & 2 & 2 \\
\hline 25: Poland & 3 & 3 & 3 & 1 & 1 \\
\hline 26: Portugal & 5 & 4 & 3 & 1 & 1 \\
\hline 27: Romania & 1 & 1 & 1 & 1 & 1 \\
\hline 28: Slovak Republic & 3 & 3 & 3 & 1 & 1 \\
\hline 29: Slovenia & 1 & 1 & 1 & 1 & 1 \\
\hline 30: Spain & 5 & 4 & 3 & 1 & 1 \\
\hline 31: Sweden & 2 & 2 & 2 & 2 & 2 \\
\hline 32: United Kingdom & 4 & 2 & 2 & 2 & 2 \\
\hline & & & & & \\
\hline & & 5 & 1 & 2 & 2 \\
\hline
\end{tabular}

Note: Ward's method and Squared Euclidean distance measure are applied to perform the hierarchical cluster analysis.

Source: Authors' calculations

The top 12 best EU countries in the Euclidean distance chart (Figure 6a) are widely dispersed across clusters \#2, \#4, and \#6 (Table 3 ). 
Olivera Kostoska, Ilija Hristoski •ICTs and innovation for competitiveness: Evidence...

Table 3: Cluster membership of WB and EU-28 ( $\mathrm{N}=6$ clusters)

\begin{tabular}{|c|l|}
\hline Cluster & \multicolumn{1}{|c|}{ Country } \\
\hline$\# 1$ & $\begin{array}{l}\text { Albania, Montenegro, Macedonia, Serbia, Bulgaria, Croatia, Cyprus, Greece, } \\
\text { Hungary, Romania, Slovenia }\end{array}$ \\
\hline$\# 2$ & Austria, Belgium, Denmark, Finland, Ireland, Netherlands, Sweden \\
\hline$\# 3$ & Czech Republic, Estonia, Latvia, Lithuania, Poland, Slovak Republic \\
\hline$\# 4$ & France, Germany, United Kingdom \\
\hline$\# 5$ & Italy, Portugal, Spain \\
\hline$\# 6$ & Luxembourg, Malta \\
\hline
\end{tabular}

Source: Authors' calculations

Finally, hierarchical clustering produces a dendrogram (Figure 7), i.e. a tree diagram commonly used to illustrate the arrangement of clusters. The latter contains many U-shaped lines linking objects in a hierarchical tree.

Figure 7: Dendrogram depicting hierarchical clustering of WB and EU-28

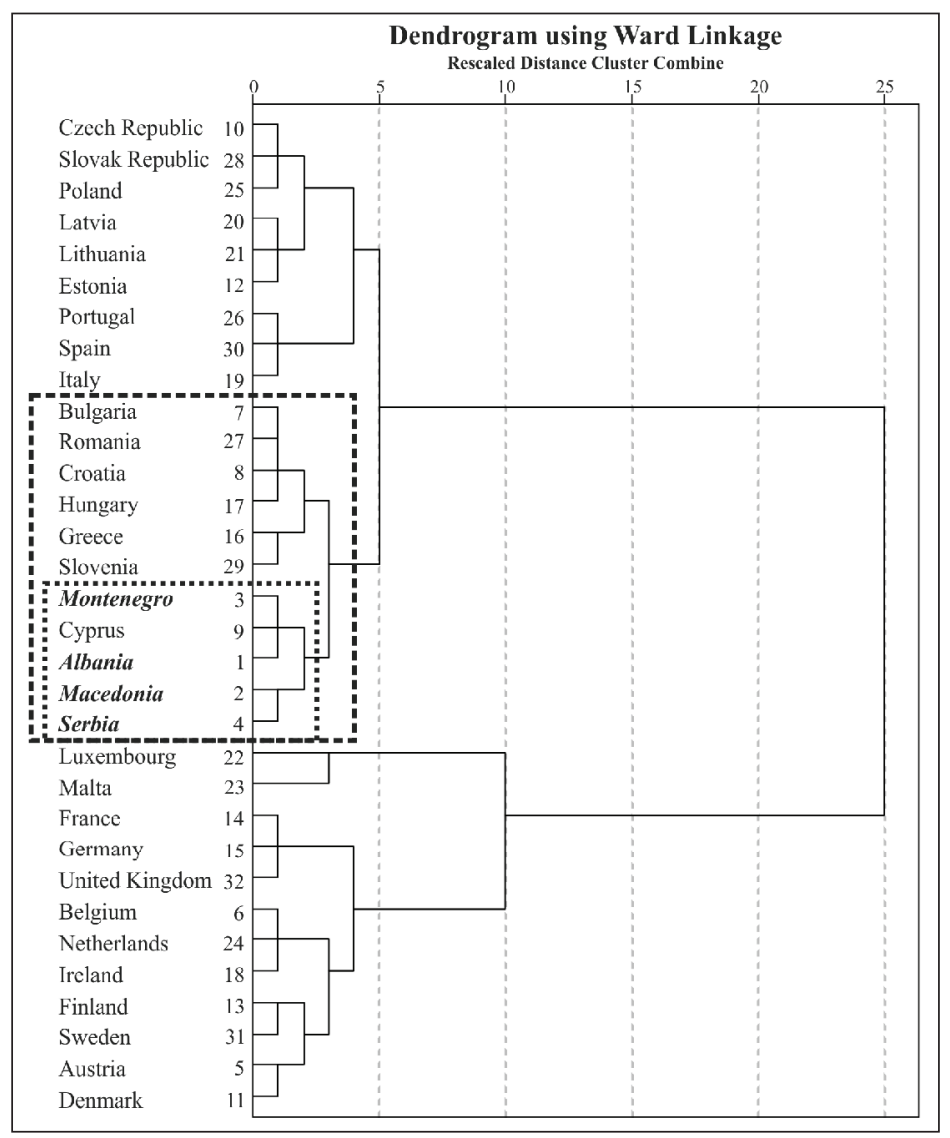

Source: Authors' calculations 
The height of each $\mathrm{U}$ represents the distance between two objects being connected. Every single leaf in the dendrogram corresponds to one data point (i.e. a country). This figure completely refers to Table 3, visualising and presenting the position of Western Balkan countries and the subgroup of seven EU member states in cluster $\# 1$ ( $\mathrm{N}=6$ clusters). The $12 \mathrm{EU}$ countries bunched at the bottom of the chart entirely correspond to the group of top 12 countries (clusters \#2, \#4, and \#6) initially presented in the Euclidean distance chart (Figure 6a).

\section{Results and discussion}

As Europe slowly emerges from the worst financial and economic crisis of the last 80 years, the need to concentrate on long-term strategies to improve competitiveness has never been greater. Following the vision set out by Europe 2020 strategy, all stakeholders must work together in building a smarter, inclusive and sustainable economy to support robust economic growth and the creation of jobs. As candidate countries for EU membership, Western Balkans (Albania, Macedonia, Montenegro and Serbia) are expected to act in accordance with these goals. The 'distance' between WB average and individual EU countries, the cluster analysis and dispersion in performance across Western Balkan and EU countries clearly indicate that the EU is far from a homogenous entity in terms of competitiveness i.e. large disparities exist among member states. For example, North-Western Europe and Northern Europe boast innovative economies, while Southern and Central and Eastern Europe are trailing behind. Likewise, Europe is divided digitally, with well-performing North (Denmark, Finland and Sweden) and North-West (led by Luxemburg, Netherlands, Germany and UK), compared with a lagging South and East. The findings also show that EU candidate countries depict a competitiveness profile similar to that of Central and Eastern Europe. In view of this dispersion in performance across European countries, the empirical analysis conducted here actually provides a framework to clearly identify the EU member states that would represent a 'real benchmark' for WB when aiming to assess competitiveness, i.e. these are the countries that belong in the same cluster as Western Balkans.

Preparing the countries for accession will require addressing their specific competitiveness weaknesses. Overall, the Western Balkans have not managed to match the EU-28 average when it comes to laying the foundations for 'smart growth'. The findings suggest that the region is trailing behind the comparator countries in building a smarter economy that can help facilitate a transition to higher value added, more productive activities. This gap in creating a knowledgebased economy is evident in all 'smart growth' pillars, i.e. pillar 5 (higher education and training), pillar 9 (technological readiness), pillar 11 (business sophistication) and pillar 12 (innovation). 
A highly skilled and educated workforce is critical for those economies that wish to move up the value chain beyond simple processes and products. The quality of education and ability of the educational system to deliver the necessary skills to find rewarding employment is crucial (World Economic Forum, 2014). Nevertheless, the EU does outperform the WB in all indicators grouped into the "higher education and training' pillar (e.g. tertiary education enrolment rate, quality of the education system, quality of management schools, local availability of specialized training services, extent of staff training etc.).

Technology is increasingly important for companies to compete and prosper. "Whether the technology used has or has not been developed within national borders is irrelevant for its ability to enhance productivity. The central point is that the firms operating in the country need to have access to advanced products and blueprints and the ability to absorb and use them" (World Economic Forum, 2015: 36). In this context, Foreign Direct Investment (FDI) plays a decisive role for those countries at a less advanced stage of technological development. Nevertheless, majority of FDI in WB has become heavily biased towards banking, real estate and other local market seeking sectors, and thereby contributed much less to build up a competitive and sufficiently sized tradable sector which would lead to efficiency seeking FDI (Radosevic, 2014). In fact, it is the same worrying trend all over again, the negative percentage change (WB vis-à-vis EU-28 average) in all indicators that belong to the 'technological readiness' pillar (e.g. fixed-broadband Internet subscriptions, Internet bandwidth, mobile-broadband subscriptions etc.) which measures the agility with which the countries adopt existing technologies, with special emphasis on the extent to which an economy has harnessed ICTs to share knowledge and increase its industries' productivity.

The same holds true for the 'business sophistication' pillar, which concerns two components that are intricately linked: the quality of the country's overall business networks and the quality of the individual companies' operations and strategies. These factors are particularly important when the more basic sources of productivity improvements have been largely exhausted (World Economic Forum, 2015).

Generally, innovation can develop from new technological and non-technological knowledge. The latter are closely related to factors that are embedded in organizations and are therefore mainly covered by the 'business sophistication' pillar. However, the WB are also performing worse than EU countries on most indicators (six out of seven) related to technological innovation as captured by the final GCI pillar of competitiveness (i.e. innovation). In the long run, standards of living can be largely improved by technological innovation. As well as making maximum use of existing technologies, as discussed in the 'technological readiness' pillar, the countries must obtain the necessary framework to ensure that they are at the forefront of innovation. In particular, this means sufficient investment in research and development (R\&D), especially by the private sector; the existence of 
high-quality scientific research institutions that can produce the basic knowledge required to build the new technologies; and university-industry collaboration in R\&D to facilitate the translation of fundamental research into high value-added products. In addition, comparatively low patent application numbers show not only a low level of innovation, but may also reflect the deficiency of knowledge and capacity of SMEs to efficiently manage the process of filing patents. Given the importance of intellectual property in attracting investment, "protecting against competitors and distinguishing businesses from one another, policies and information-sharing to facilitate patent filing, particularly for young companies, could help close the gap" (World Economic Forum, 2014: 18).

The results overall also indicate that WB are outdistanced in laying the foundations for 'inclusive growth'. This can be seen reflected in the region's worse performance regarding that of EU on majority of GCI indicators (e.g. cooperation in labouremployer relations, pay and productivity, country capacity to retain talent, country capacity to attract talent, female participation in the labour force, etc.) that belong to 'labour market efficiency' pillar. Generally, the flexibility and efficiency of labour market are crucial for making sure that workers are allocated to their most effective use and motivated to give their best efforts in jobs. Consequently, labour markets must have the flexibility to move workers from one economic activity to another promptly and at low cost, and to permit wage fluctuations without much social disruption (Amin, 2009; Kaplan, 2009).

\section{Conclusions}

Nowadays, with the acute phase of the economic and financial crisis in the past, and with signals of moderate but uneven growth and slow job recovery amid a number of frailties and risks in Europe, it is clear that renewed actions in terms of engaging in much-needed structural reforms and productivity-increasing investments are required. These measures are not only crucial, as they have always been, but they are also turning out to be urgent if Europe is to transform itself into a smart, sustainable and inclusive economy, delivering new opportunities and new jobs for larger segments of population. Similarly, the 2008 global and European financial and economic crisis has made the existing economic problems in Western Balkans worse by adding two additional external shocks: a smaller influx of capital from abroad and the collapse of export demand. Moreover, the crisis has imposed a negative social impact, resulting in enhanced poverty and lower living standards. Against this backdrop, Western Balkans need to bring the competitiveness agenda back to the heart of economic policy by addressing the factors that determine the region's level of productivity. This is even more important when one considers that these countries were granted the official EU candidate status and thus, they have the potential to become full members at some point, which will certainly 
make them bound to the Europe's overall goals. With the Global Competitiveness Index 2015-2016, this paper tries to gauge both the level of competitiveness of Western Balkans and the region's relative position vis-à-vis the EU member states. The major disadvantage of any study based solely on rankings is that the ordinal scale does not reflect the appropriate competitiveness level of a country (entity) relative to other countries (entities). The exact position of a given country (entity) within the total configuration can only be assessed after performing the grouping of nations and identifying similarities in terms of competitiveness. For that reason, this article uses both Euclidean and statistical distances, as well as the hierarchical cluster analysis approach to measure the Western Balkans' 'distance' from each EU member state within the multidimensional data space. To the best of our knowledge, the methodology proposed here has not been used before to estimate the economic competitiveness of Western Balkan candidate countries, providing a sense of the challenges they currently face and a framework to identify the overall strengths and weaknesses which are more important to the future than to present or past. Strictly speaking, the application of this method permits us both to successfully gauge how well prepared the countries are to join the EU in terms of competitiveness (i.e. which attributes are the most important to ensure that they will contribute effectively to overall European competitiveness) and to clearly identify the set of EU countries that would represent a 'real benchmark' for Western Balkans when trying to assess the region's competitiveness. Hence, this work aims to contribute new knowledge in different ways both to the recent literature and policy discussions for building a more competitive region and steady convergence of the Western Balkan economies. The major limitation is that the outliers in cluster analysis may distort the Euclidean distances and hence the clustering outcome. Moreover, the cluster definition issue is NP-complete and thus, a computationally efficient exact solution method does not exist. The main problem with any clustering technique is how to select the number of clusters. Various clustering methods may lead to different clusters, and the differences are generally attributable to the inherent features of the methodology used. In fact, there is no single methodology to be recommended for selecting the most appropriate number of clusters and the most suitable clustering method. That is why cluster analysis is usually acknowledged to be more of an art than a science. Looking at comparisons between EU member states and Western Balkans, a persistent divide between the economies prevails. The results clearly show that the EU is different from being a homogenous entity in terms of competitiveness (i.e. important disparities exist among member countries), whilst the candidates exhibit competitiveness profiles similar to those of Central and Eastern Europe. Overall, the basic hypothesis of the research is confirmed, viz. Western Balkans are significantly outdistanced in laying the foundations for 'smart growth' and trail behind the EU-28 in building knowledge-intensive economy distinguished by a supporting environment for business activities and innovative framework that opens the door for translating fundamental research into marketable, high-value added products. The gap to EU 
countries is evident in all 'smart' growth pillars, i.e. higher education and training, technological readiness, business sophistication and innovation, where the Western Balkans clearly falls short compared to EU-28 average. This raises concerns about the region's overall ability to increase competitiveness and its potential to provide rising living standards. Considerable room for improvement also remains along the 'inclusive growth', in view of the high and persistent levels of unemployment, particularly for the youth, accompanied by comparatively stronger rigidities in labour markets of some Western Balkan countries. In this regard, continuing the process of economic diversification, which is essential to boost exports and FDI in higher value-added industries, emphasizing efforts to educate and train WB's youth (e.g. reforming and modernizing universities) will be the critical lever both for a smart and more inclusive economy. Put differently, addressing investment gaps in significant intangible assets, such as public- and private-sector R\&D, ICTs and skills development schemes for gainful employment in an increasingly knowledgedriven economy will be the most essential to achieve a more competitive region. These investments will need to go closely together with policies that produce favourable business conditions for entrepreneurship and innovation. Short-term troubles from economic structural change caused by these policies and investments would need to be alleviated by supplementary measures to facilitate and accelerate the transformation processes. In the long run, investments and policies for smart growth will build the prospects for gainful employment and cater to a socially inclusive region. Against this backdrop, effective governance mechanisms and institutional capacity to implement and monitor the change remain critical success factors, as is the need to set up shared commitments from all stakeholders of the economy. In essence, our analysis attempts to provide guidance to decision makers for those areas where policy interventions may possibly boost productivity, employment and prosperity, but does not explicitly cover the most appropriate types of policy interventions (and policy mix). The future research will likely contribute to fill this gap drawing a number of valuable indications from the analysis reported here. In addition, this paper assesses competitiveness of Western Balkans vis-à-vis the EU-28, whilst the results clearly show that large disparities exist among the Member States, with some countries performing better and others far worse. Hence, the future research may evaluate the WB competitiveness in relation to and make a comparative analysis with a set of countries that perform in a similar fashion, especially in terms of developing smart economies and represent an overall feasible target for the candidate countries, that is some of those Member States that have joined the EU since 2004. 


\section{References}

Aboal, D., Tacsir, E. (2015) "Innovation and Productivity in Services and Manufacturing: The Role of ICT Investment", UNU-MERIT Working Papers [Internet], \#2015-012, ISSN 1871-9872. Available at: <http://www.merit.unu. edu/publications/working-papers/abstract/?id $=5643>$ [Accessed: April 7, 2016].

Amin, M. (2009) "Labor regulation and employment in India's retail stores", Journal of Comparative Economics, Vol. 37, No. 1, pp. 47-61, doi: 10.1016/j. jce.2008.07.001.

Arvanitis, S., Loukis, E. N. (2009) "Information and communication technologies, human capital, workplace organization and labour productivity: A comparative study based on firm-level data for Greece and Switzerland", Information Economics and Policy, Vol. 21, No. 1, pp. 43-61, doi: 10.1016/j. infoecopol.2008.09.002.

Atrostic, B. K. et al. (2004) "IT, Productivity and Growth in Enterprises: New Results from International Micro Data”. In OECD, ed., The Economic Impact of ICT-Measurement, Evidence and Implications, Paris: OECD.

Basu, S. et al. (2004) "The case of the missing productivity growth, or does information technology explain why productivity accelerated in the United States but not in the United Kingdom?". In Gertler, M., Rogoff, K. ed., NBER Macroeconomics Annual 2003, Cambridge, MA: The MIT Press, doi: 10.1086/ ma.18.3585244.

Baumann, J., Kritikos, A. S. (2016) "The Link between R\&D, Innovation and Productivity: Are Micro Firms Different?", IZA discussion paper [Internet], No. 9734. Available at: <http://ftp.iza.org/dp9734.pdf> [Accessed: November 23, 2017].

Biagi, F. (2013) ICT and Productivity: A Review of the Literature, Luxembourg: Publications Office of the European Union (JRC Technical Reports, Institute for Prospective Technological Studies, Digital Economy Working Paper, 2013/09).

Bloom, N., Sadun, R., Van Reenen, J. (2012) "Americans do IT better: U.S. multinationals and the productivity miracle", American Economic Review, Vol. 102, No. 1, pp. 167-201, doi: 10.1257/aer.102.1.167.

Boltho, A. (1996) "The assessment: international competitiveness", Oxford Review of Economic Policy, Vol. 12, No. 3, pp. 1-16, doi: 10.1093/oxrep/12.3.1.

Bresnahan, T. F., Trajtenberg, M. (1995) "General Purpose Technologies 'Engines of Growth'?", Journal of Econometrics, Vol. 65, No. 1, pp. 83-108, doi: 10.1016/0304-4076(94)01598-T.

Brynjolfsson, E., Hitt, L. (1995) "Information Technology as a Factor of Production: the Role of Differences among Firms", Economics of Innovation and New Technology, Vol. 3, No. 3-4, pp. 183-200, doi: 10.1080/10438599500000002. 
------ (2003) “Computing productivity: firm-level evidence”, Review of Economics and Statistics, Vol. 85, No. 4, pp. 793-808, doi: 10.1162/003465303772815736.

Cantwell, J. (2005) "Innovation and competitiveness". In Fagerberg, J., Mowery, D., Nelson, R. ed., The Oxford Handbook of Innovation, Oxford: Oxford University Press.

Cardona, M., Kretschmer, T., Strobel, T. (2013) "ICT and productivity: conclusions from the empirical literature", Information Economics and Policy, Vol. 25, No. 3, pp. 109-125, doi: 10.1016/j.infoecopol.2012.12.002.

Cho, D., Moon, H. (2013) International Review of National Competitiveness: A Detailed Analysis of Sources and Rankings, Edward Elgar Publishing Limited.

Conte, A., Vivarelli, M. (2014) "Succeeding in Innovation: Key Insights on the Role of R\&D and Technological Acquisition Drawn from Company Data", Empirical Economics, Vol. 47, No. 4, pp. 1317-1340, doi: 10.1007/s00181013-0779-1.

Crepon, B., Duguet, E., Mairessec, J. (1998) "Research, Innovation and Productivity: An Econometric Analysis at the Firm Level", Economics of Innovation and New Technology, Vol. 7, No. 2, pp. 115-158, doi: 10.1080/10438599800000031.

Criscuolo, C. (2009) "Innovation and Productivity: Estimating the Core Model Across 18 Countries". In OECD ed., Innovation in Firms: A Microeconomic Perspective, France: OECD Publishing.

Daveri, F. (2003) "Information Technology and Productivity Growth Across Countries and Sectors", SSRN Electronic Journal [Internet], IGIER Working Paper No. 227. Available at: $<$ https://ssrn.com/abstract=371583 $>$ or $<$ http://dx. doi.org/10.2139/ssrn.371583> [Accessed: April, 15, 2016].

Djogo, M., Stanisic, N. (2016) "Is the Global Competitiveness Report the right measure of macroeconomic competitiveness", Zbornik radova Ekonomskog fakulteta u Rijeci: časopis za ekonomsku teoriju i praksu/Proceedings of Rijeka Faculty of Economics: Journal of Economics and Business, Vol. 34, No. 1, pp. 91-117, doi: 10.18045/zbefri.2016.1.91.

Dragašević, M. (2014) "South East European 2020 Strategy and Relevance of the Smart Growth Pillar". In Marinkovic, I., Dall, E. ed., $R \& D$ and Innovation in Western Balkans: Moving Towards 2020, Wien: WBC-INCO.NET c/o ZSI Centre for Social Innovation.

European Commission (2010) Commission Staff Working Document, Brussels: SEC(2010) 627 (Europe's Digital Competitiveness Report, Vol. I).

Fagerberg, J. (1996) "Technology and competitiveness", Oxford Review of Economic Policy, Vol. 12, No. 3, pp. 39-51, doi: 10.1093/oxrep/12.3.39.

García-Quevedo, J., Pellegrino, G., Vivarelli, M. (2014) "R\&D Drivers and Age: Are Young Firms Different?", Research Policy, Vol. 43, No. 9, pp. 1544-1556, doi: 10.1016/j.respol.2014.04.003. 
Gilchrist, S., Gurbaxani, V., Town, R. (2001) Productivity and the PC Revolution, University of California, Irvine: Center for Research on Information Technology and Organizations (Tech. Rep.).

Gordon, R. J. (2000) "Does the New Economy Measure up to the Great Inventions of the Past?", Journal of Economic Perspectives, Vol. 14, No. 4, pp. 49-74, doi: 10.1257/jep.14.4.49.

- (2012) "Is US economic growth over? Faltering innovation confronts the six headwinds", CEPR Policy Insight [Internet], No. 63. Available at: http://www. cepr.org/sites/default/files/policy_insights/PolicyInsight63.pdf [Accessed: May $10,2016]$.

Griffith, R. et al. (2006) "Innovation and Productivity across four European Countries", Oxford Review of Economic Policy, Vol. 22, No. 4, pp. 483-498, doi: 10.1093/oxrep/grj028.

Griliches, Z. (1979) "Issues in Assessing the Contribution of Research and Development to Productivity Growth", The Bell Journal of Economics, Vol. 10, No. 1, pp. 92-116, doi: 10.2307/3003321.

Hall, B. H. (2011) "Innovation and Productivity", NBER working paper series [Internet], No. 17178. Available at: <http://www.nber.org/papers/w17178.pdf > [Accessed: November 23, 2017], doi: 10.3386/w17178.

Hristoski, I., Kostoska, O. (2017) "System dynamics approach for the economic impacts of ICTs: evidence from Macedonia", Information Development, doi: 10.1177/0266666917702430.

Inklaar, R., Timmer, M. P., van Ark, B. (2007) "Mind the gap! International comparisons of productivity in services and goods production", German Economic Review, Vol. 8, No. 2, pp. 281-307, doi: 10.1111/j.1468-0475.2007.00408.x.

Jorgenson, D. W., Ho, M. S., Stiroh, K. J. (2002) "Projecting Productivity Growth: Lessons from the U.S. Growth Resurgence", Federal Reserve Bank of Atlanta Economic Review, Vol. 87, No. 3, pp. 1-13.

------ (2008) "A Retrospective Look at the U.S. Productivity Growth Resurgence", Journal of Economic Perspectives, Vol. 22, No. 1, pp. 3-24, doi: 10.1257/ jep.22.1.3.

Jorgenson, D. W., Timmer, M. P. (2011) "Structural change in advanced nations: a new set of stylised facts", Scandinavian Journal of Economics, Vol. 113, No. 1, pp. 1-29, doi: 10.1111/j.1467-9442.2010.01637.x.

Kaplan, D. S. (2009) "The Effects of Rigid Labor Regulations in Latin America", World Bank Group, Enterprise Note Series [Internet], No. 4. Available at: $<$ http://documents.worldbank.org/curated/en/723991468046164481/Theeffects-of-rigid-labor-regulations-in-Latin-America> [Accessed: May 25, 2016].

Kostoska, O., Hristoski, I. (2016) "On the Pulse of ICT Revolution, Productivity, and Growth: Macedonia versus European Union". In Proceedings of the $6^{\text {th }}$ 
International Conference on Applied Internet and Information Technologies, 3-4 June, Bitola, Macedonia, pp. 358-374, doi: 10.20544/aiit2016.44.

Kostoska, O., Mitrevski, P. (2016) "Evaluating foreign trade specialization and qualitative competitiveness of a transition economy: the case of Macedonia", Empirica. Journal of European Economics, Vol. 43, No. 3, pp. 633-655, doi: 10.1007/s10663-015-9308-0.

Lall, S. (2001) "Competitiveness Indices and Developing Countries: An Economic Evaluation of the Global Competitiveness Report", World Development, Vol. 29, No. 9, pp. 1501-1525, doi: 10.1016/s0305-750x(01)00051-1.

Marrano, M. G., Haskel, J., Wallis, G. (2009) "What happened to the knowledge economy? ICT, intangible investment, and Britain's productivity record revisited", Review of Income and Wealth, Vol. 55, No. 3, pp. 686-716, doi: 10.1111/j.1475-4991.2009.00344.x.

Mohnen, P., Hall, B. H. (2013) “Innovation and Productivity: An Update”, Eurasian Business Review, Vol. 3, No. 1, pp. 47-65.

OECD (2008) Handbook on Constructing Composite Indicators: Methodology and User Guide, France, doi: 10.1787/9789264043466-en.

Oliner, S. D., Sichel, D. E. (2000) "The Resurgence of Growth in the Late 1990s: Is Information Technology the Story?", Journal of Economic Perspectives, Vol. 14, No. 4, pp. 3-22, doi: 10.1257/jep.14.4.3.

(2002) "Information Technology and Productivity: Where Are We Now and Where Are We Going?", Federal Reserve Bank of Atlanta Economic Review, Vol. 87, No. 3, pp. 15-44.

Önsel, S. et al. (2008) "A new perspective on the competitiveness of nations", Socio-Economic Planning Sciences, Vol. 42, No. 4, pp. 221-246, doi: 10.1016/j. seps.2007.11.001.

Oulton, N., Srinivasan, S. (2005) "Productivity growth in UK industries, 19702000: Structural Change and the Role of ICT", Bank of England, Working Paper [Internet], No. 259. Available at: <http://www.bankofengland.co.uk/ archive/Documents/historicpubs/workingpapers/2005/wp259.pdf $>$ [Accessed: November 23, 2017], doi: 10.2139/ssrn.824104.

Parisi, M., Schiantarelli, F., Sembenelli, A. (2006) "Productivity, Innovation and R\&D: Micro Evidence for Italy", European Economic Review, Vol. 50, No. 8, pp. 2037-2061, doi: 10.1016/j.euroecorev.2005.08.002.

Pianta, M., Vaona, A. (2006) "Innovation and productivity in European Industries", Kiel Institute for the World Economy, Kiel Working Paper [Internet], No. 1283. Available at: <https://www.econstor.eu/bitstream/10419/3842/1/kap1283.pdf> [Accessed: May 25, 2016].

Polder, M. et al. (2010) "Product, Process and Organizational Innovation: Drivers, Complementarity and Productivity Effects", UNU-MERIT working papers 
[Internet], \#2010-035. Available at: <https://ideas.repec.org/p/unm/ unumer/2010035.html> [Accessed: May 25, 2016].

Porter, M. E. (1990) The Competitive Advantage of Nations, New York: Free Press, doi: 10.1007/978-1-349-11336-1.

Radosevic, S. (2014) "Technology Upgrading and RTD Challenges in Western Balkan Region: Issues and Policy Options". In Marinkovic, I., Dall, E. ed., $R \& D$ and Innovation in Western Balkans: Moving Towards 2020, Wien: WBCINCO.NET c/o ZSI - Centre for Social Innovation.

Rincon, A., Vecchi, M. (2010) "Short run and long run ICT spillovers: microeconomic evidence", mimeo [Internet]. Available at: <https://community. oecd.org/docs/DOC-32094> [Accessed: November 23, 2017].

Rostow, W. W. (1960) The Stages of Economic Growth: a Non-Communist Manifesto, Cambridge: University Press.

Sala-i-Martín, X. et al. (2007) "The Global Competitiveness Index: Measuring the Productive Potential of Nations". In The Global Competitiveness Report 20072008, Hampshire: Palgrave Macmillan.

Segota, A., Tomljanovic, M., Hudjek, I. (2017) "Contemporary approaches to measuring competitiveness - the case of EU member states", Zbornik radova Ekonomskog fakulteta u Rijeci: časopis za ekonomsku teoriju i praksul Proceedings of Rijeka Faculty of Economics: Journal of Economics and Business, Vol. 35, No. 1, pp. 123-150, doi: 10.18045/zbefri.2017.1.123.

Solow, R. M. (1987) “We'd Better Watch Out”, New York Times Book Review [Internet], pp. 36. Available at: <http://www.standupeconomist.com/pdf/misc/ solow-computer-productivity.pdf $>$ [Accessed: May 25, 2016].

Van Ark, B., O’Mahony, M., Timmer, M. P. (2008) "The Productivity Gap between Europe and the United States: Trends and Causes", Journal of Economic Perspectives, Vol. 22, No. 1, pp. 25-44, doi: 10.1257/jep.22.1.25.

Van Reenen, J. et al. (2010) The Economic Impact of ICT, LSE: Center for Economic Performance (Final Report, Smart N. 2007/0020).

Vujović, D. (2014) “Western Balkans Regional R\&D Strategy for Innovation”. In Marinkovic, I., Dall, E. ed., R\&D and Innovation in Western Balkans: Moving Towards 2020, Wien: WBC-INCO.NET c/o ZSI - Centre for Social Innovation.

World Economic Forum (2014) The Europe 2020 Competitiveness Report: Building a More Competitive Europe, Geneva: World Economic Forum.

(2015) The Global Competitiveness Report 2015-2016, Geneva: World Economic Forum. 


\title{
IKT i inovacije za konkurentnost: Zapadni Balkan vis-à-vis Europske Unije
}

\author{
Olivera Kostoska ${ }^{1}$, Ilija Hristoski ${ }^{2}$
}

\begin{abstract}
Sažetak
Cilj rada je ocijeniti koliko su zemlje Zapadnog Balkana (Albanija, Makedonija, Crna Gora i Srbija) dobro pripremljene za članstvo u EU u smislu konkurentnosti, te jasno identificirati skup zemalja EU-a koji bi predstavljao realni usporedni prag vrijednosti konkurentnosti regije. U 2010. godini, Strategija Europa 2020 predložena je kao sredstvo fokusiranja EU-a i njezinih država-članica na glavni zadatak poboljšanja konkurentnosti i stvaranja uvijeta za pametan, održiv $i$ inkluzivan rast. Očekuje se da države Zapadnog Balkana kao kandidati za članstvo u EU djeluju u skladu s ovim ciljevima. Dakle, u radu se koristi Indeks globalne konkurentnosti (GCI) 2015-2016 i skup dodatnih alata za analizu podataka s ciljem procjenjivanja razine konkurentnosti, te relativne pozicije regije naspram zemalja-članica EU-a. Rezultati jasno pokazuju da EU nije homogeni entitet u pogledu konkurentnosti, dok kandidati imaju profil konkurentnosti sličan zemljama Centralne i Istočne Europe. Općenito govoreći, zemlje Zapadnog Balkana zaostaju iza zemalja EU-28 u izgradnji gospodarstava zasnovanih na znanju, i značajno su distancirani $u$ postavljanju temelja tzv. 'pametnog rasta', koncepta kojeg Europske ekonomije snažno zastupaju.
\end{abstract}

Ključne riječi: indeks globalne konkurentnosti (GCI), informacijske i komunikacijske tehnologije (IKT), inovacije, Zapadni Balkan, EU

JEL klasifikacija: O52, O57

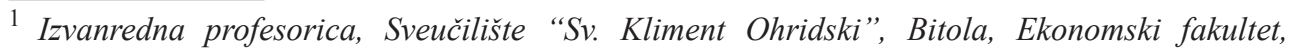
Marksova 133, 7500 Prilep, Makedonija. Znanstveni interes: međunarodna trgovina $i$ investicije, produktivnost, inovacije i Europska integracija. Tel.: +38948427 020. Fax: +389 48426 927. E-mail: olivera.kostoska@uklo.edu.mk. Osobna web stranica: http://www.eccfp. uklo.edu.mk/teachers/view/72 (osoba za kontakt).

2 Docent, Sveučilište "Sv. Kliment Ohridski”, Bitola, Ekonomski fakultet, Marksova 133, 7500 Prilep, Makedonija. Znanstveni interes: modeliranje i evaluacija performabilnosti sustava za elektronsku trgovinu temeljenih na ponašanju, Petrijeve mreže, diskretne simulacije, pristup sustavnog razmišljanja i sustavna dinamika. Tel.: +38948427 020. Fax: +38948426927. E-mail: ilija.hristoski@uklo.edu.mk. Osobna web stranica: http://www.eccfp.uklo.edu.mk/ teachers/view/76. 